\title{
Effects of Word Games, Culturally Relevant Songs, and Stories on Students' Motivation in a Nigerian English Language Class
}

\author{
Yetunde Ajibade and Kate Ndububa
}

This study investigated the extent to which word games and culturally relevant songs and stories could motivate senior secondary school students in Nigeria, thereby enhancing their performance in English. A pre-test/post-test control group design was used. The sample consisted of 100 senior secondary school II students randomly assigned into experimental and control groups. Four instruments were designed, validated, and used for data collection. Four hypotheses were formulated and tested. The findings revealed that the use of word games and culturally relevant instructional activities was beneficial for these students, as they served as an effective motivational strategy that contributed to better performance in English-language learning at the senior secondary school level.

Cette étude a porté sur la mesure dans laquelle l'emploi des jeux de mots et des chansons culturellement significatives pouvait motiver des élèves $d u$ secondaire au Nigeria, et donc améliorer leurs compétences en anglais. La méthodologie retenue reposait sur l'emploi d'un prétest et d'un posttest avec un groupe témoin. L'échantillon était composé de 100 élèves du secondaire II assignés au hasard à un groupe expérimental ou à un groupe témoin. La cueillette de données s'est effectuée avec quatre instruments qui avaient été conçus et validés à cette fin. Les résultats indiquent que les élèves ont profité des jeux de mots et des activités pédagogiques culturellement significatives et que l'emploi de ces outils servait de stratégie motivationnelle efficace pour améliorer leur performance dans l'apprentissage de l'anglais au niveau secondaire.

\section{Introduction}

The English language, introduced into Nigeria in the colonial period, is now recognized as a world language: it is one of the most prominent languages used for international politics, trade, sports, and social purposes. The English language now performs international functions as it helps link the multilingual societies of Africa with the wider world. It may also open the door to high technology, science, trade, and diplomacy. In Nigeria, English is the official language used to conduct legislative, executive, and judicial functions at the three levels of government: local, state, and federal. English has 
been retained for this purpose as a short-term measure so as to contribute to political stability in the country because it is believed that the choice of one of the indigenous languages might create potentially intractable problems: for the purpose of carrying out official functions, it is felt that a language like English-not associated with any specific group-may neutralize this fear.

It is regrettable that in spite of the importance of English in Nigerian society and in the curricula of primary, secondary, and tertiary institutions in Nigeria, millions of students fail to learn the language; the statistics for student results on English language external examinations between 2000 and 2003 are shown in Appendix A. Poor performance by students of English has been a source of concern for all stakeholders in the educational sector: plainly it is attributable to many factors, including but not restricted to lack of teaching materials, ineffective teaching techniques, and poorly qualified teachers. In particular, teacher weakness can be observed in terms of both content knowledge and content delivery. This article focuses on motivational activities in content delivery.

Motivation, the impetus to create and sustain intentions and goal-seeking acts (Ames, 1992), is important in the teaching-learning context because it determines the extent of learners' active involvement in and attitude to learning. In Nigeria, English language learners, especially at the secondary school level, are often cut off from motivational activities of the sort discussed in this article due to teachers' general belief that at this stage learners no longer benefit from such activities. This belief needs to be objectively examined.

\section{Statement of the Problem}

Motivation occupies a central position in second/foreign language learning. The motivational value of language-classroom activities such as charts, art projects, drama, riddles, games, songs, and stories has been recognized, especially in developed countries. These activities, which help to alleviate the drudgery of drill and practice, motivate learners and ultimately contribute to success in learning tasks. However, in Nigeria, senior secondary school students in particular continue to perform poorly in their English language classes. Could this in part be due to a dearth of effective motivational cues at this level of English language learning?

\section{Purpose of the Study}

It is assumed that senior secondary school students in Nigeria do not perform well in English at least partly because they lack the appropriate motivation that could help them develop goal-directed movements, which in turn might lead to improved success in English language learning tasks. The study aims to explore how word games and culturally relevant instructional activities such as songs and stories could be used in motivating these stu- 
dents in English language learning tasks, thereby improving their performance in the subject. Specifically, the study will:

1. provide empirical evidence for the relationship between senior secondary school students' motivational level and their performance in English;

2. assess the effect of word games and culturally relevant instructional activities like songs and stories on senior secondary school students' motivation in English;

3. measure the extent to which the selected activities influence these students' performance in English language; and

4. compare the effect of these activities on male and female senior secondary school students.

Consequently, the following research questions are asked:

1. How does the present motivational level of senior secondary school students' affect their performance in English?

2. Do word games and culturally relevant activities such as songs and stories build motivation in these students?

3. Do word games, songs, and stories influence their performance in English?

4. Do the selected instructional activities equally influence both male and female senior secondary school students' motivational levels?

\section{Research Hypotheses}

1. There is no significant relationship between senior secondary school students' present motivational level and their performance in English language.

2. There is no significant difference in the motivational level in English language of those taught through word games, songs, and stories and those taught without them.

3. There is no significant difference in the post-treatment performance in English language of those taught through word games, songs, and stories and those taught without them.

4. There is no significant difference between the post-treatment motivational levels of male and female senior secondary school students in English language.

\section{Theoretical Framework}

The theoretical framework for this study is based on the work of Maslow (1954), whose concept of motivation centers around the satisfaction of basic needs such as those for food, shelter, love, and the maintenance of positive self-esteem. Individuals differ in the degree of importance they attach to each of such needs: some need continual reaffirmation that they are loved or appreciated; others have a greater need for physical comfort and security. 
The importance of Maslow's (1954) theory lies in the relationship between deficiency needs and growth needs. Students who are hungry or who are in physical danger will have little psychological energy to put into learning. Schools and government agencies recognize that if students' basic needs are not met, learning will suffer. The most important deficiency needs, however, may be those for love and self-esteem. Students who feel that they are not loved or that they are not capable of being loved are unlikely to have a strong motivation to achieve higher-level growth objectives such as the search for knowledge and understanding for their own sake or creativity and openness to new ideas that are characteristic of self-actualization. This perspective suggests that students who are unsure of how well they are loved or of their capability to attract love will tend to make the safe choice: that is, they will go with the crowd, study for the test without interest in learning the ideas, and write a predictable but uncreative essay. Thus teachers who can put students at ease and make them feel accepted and respected as individuals would seem more likely (in Maslow's view) to help them become eager to learn for the sake of learning and willing to risk being creative and open to new ideas. The learning theory of motivation proposed by Maslow (with its focus on needs satisfaction as a way of motivating learners) is highly applicable to this study. Learners' ultimate learning needs are paramount for any teacher who looks for a means to put students at ease so as to obtain maximum participation and understanding from them.

\section{Motivating Students in the English Language Classroom}

More specifically, students' motivation refers to their willingness, need, desire, and compulsion to participate and be successful in the learning process (Bomia et al., 1997). According to Brophy (1986), motivation to learn is a competence acquired through general experience, but stimulated most directly through modeling, communication of expectations, and direct instruction or socialization by significant others, especially parents and teachers. And developmental changes comprise one more strand in the motivational web. On the one hand, Ames (1992) states that whereas young children tend to maintain high expectations for success even in the face of repeated failure, older students do not. Younger pupils tend to see effort as uniformly positive, whereas older learners view it as a double-edged sword: to them, failure following high effort appears to carry more negative implications, especially for their self-concept of ability, than does failure resulting from minimal or no effort. On the other hand, Anderman, and Midgeley (1998) state that the focus on motivation need not be directed toward a particular category of students because all students would benefit from higher levels of engagement and motivation to succeed. It may be argued that the teachers who are most successful in engaging learners are those who 
develop activities with students' basic psychological and intellectual needs in mind.

\section{The Use of Culturally Relevant Instructional Activities in Motivating Students to Learn English}

Activities such as charts, art projects, drama, riddles, songs, stories, and games could be used to motivate learners in the English language class with attendant positive results. However, some could be used more effectively than others depending on the context, style of use, and cultural proximity. The effect of games, songs, and stories, which form an integral part of Nigerian students' everyday lives, is examined more closely.

Games. Word games fall into this category. Games are task-based and have a purpose beyond the production of correct speech. They are an example of the most preferable communicative activities: this type of activity highlights not only the competence, but also the performance of the learner. Thus it is an indispensable part of any English lesson because it reinforces the form-discourse match. Games involving competition are organized according to rules; they are enjoyable and also collaborative: most require choral responses or group work. Through well-planned games, learners can practice and internalize vocabulary, grammar, and structures extensively. The elements of play and competition provided by games enhance the motivation of the students. They also reduce stress in the classroom. While competing, learners' attention is on the message, not on the language code. In a way, students acquire language unconsciously as their whole attention is engaged by the activity. And by tapping into personal, social, and cross-cultural issues, games sometimes simulate real-life situations.

Teachers who do not use games are neglecting one of the most vital of teaching practices. Not only do learners enjoy the competition in itself, but also such activity can furnish them with an incentive to learn that is largely absent otherwise. Word games will provide a reality that excites pupils' interest. Moreover, using such activities increases both cooperation and competition in the classroom. Thus classroom strategies with a potential for joyful, enthusiastic, and successful learning are created.

Songs. Singing is an enchanting and culturally rich resource that can easily be used in language classrooms. Songs offer a change from routine classroom activities. They are precious resources for developing students' abilities in listening, speaking, reading, and writing; they could also be used to teach a variety of language items such as sentence patterns, vocabulary, pronunciation, rhythm, adjectives, and adverbs. As stated by Lo and Fai Li (1998), learning English through songs also provides a nonthreatening atmosphere for students, who usually are tense when speaking English in a formal classroom setting. 
Furthermore, songs give new insights into the target culture. They are a means by which cultural themes can be presented effectively. Because songs offer exposure to authentic texts, they provide access to motivating prosodic features of language such as stress, rhythm, and intonation; thus through songs, classroom language-which is so often cut up into a series of structural points-becomes whole again. For example, Allen and Vallette (1977) recommend using songs to reinforce a point in grammar and to establish clear articulation. Brocklehust (1971), Allen and Vallette, and Mackay (1965) all suggest that through its process of verbal repetition and frequent drilling, singing is an activity that can provide intellectual stimulation and thus help learners fix learning skills in their minds. And Adeyanju (1996) conducted an experimental study in which one group of students was repeatedly engaged in singing folk songs, whereas the control group was repeatedly taught the same passage in a reading class; a post-treatment comprehension test indicated that the experimental group performed significantly better than the control group.

There are many advantages of using songs in the classroom. Through using contemporary popular songs, which are already familiar to teenagers, teachers can meet the challenge of addressing teenage needs in the classroom. Songs are so highly memorable and motivating that many of them constitute a powerful subculture with its own rituals. Furthermore, traditional folk songs can broaden learners' knowledge of the target culture. Correctly chosen, traditional songs have the dual motivating effect of lively tunes and interesting stories, plus for many students the added ingredient of novelty (Hill, 1999).

In consequence, if selected properly and adopted carefully, songs can be beneficial in all phases of English teaching. Songs may be used in both the presentation and the practice phase of the English lesson. They may encourage extensive and intensive listening and inspire creativity and use of the imagination in a relaxed classroom atmosphere. When selecting a song, the teacher should take into consideration the age and interests of the learners and the language used in the song itself. To enhance learners' commitment, it is also beneficial to allow them to take part in the selection process.

Stories. These offer not only an ideal way to introduce English, but also a contribution to learners' overall development, and they can be a starting point for a wide range of activities. Stories are effective as educational tools because they are believable, easy to recollect, and entertaining (Neuhauser, 1993). Their believability stems from the fact that stories deal with human or human-like experiences that we tend to perceive as an authentic and credible source of knowledge. Stories make information more retrievable because they involve us in the actions and intentions of the characters. In so doing, stories invite, indeed demand, active meaning-making. 
Bruner (1986) explains that a story can develop both the "landscape of action" and the "landscape of consciousness" (p. 14), the element of human intention. As an audience, we engage with stories on both of these levels, and it is through this dual involvement that we enter into the minds of the characters and into the deeper meaning of the narrative. We must fill in what is unspoken from our own store of knowledge. In so doing, we create as well as discover meaning, and we ask questions that we ourselves need to answer.

The learner-involvement factor is also related to the power of stories to stimulate an emphatic response. It is the particularity of the story-the specific situation, the small details, the vivid images of human experiencethat evokes a fuller response than does a simple statement of fact. This detail provides the raw material for both cognitive appreciation and affective response to the experience of another person. This dynamism is precious for educational programs that aim to foster tolerance, appreciation of diversity, and a capacity for perspective-taking (Rossiter, 1992). Stories educate as instruments of transformation as well as information (Jackson, 1995). Because stories lead from the familiar to the unfamiliar, they provide an entry into personal growth and change. Clark (2001) notes that it is when one can identify with a character who has changed that one can envisage and embrace the possibility of change for oneself. Stories of achievement and transformation can function as motivators, pathfinders, and sources of encouragement for struggling adult or young adult learners. In short, stories expose us to new knowledge, broader perspectives, and expanded possibilities.

In summary, word games, songs, and stories can all be invaluable resources in the teaching of English. According to the needs analysis for a particular classroom, a range of appropriate techniques can be integrated with such resources so as to bring the structural, pragmatic, prosodic, and communicative aspects of language together in the language-learning environment. Because teaching is a developing art that requires innovative and creative ideas to enrich its effectiveness, one must not hesitate to use such resources. These resources can assist in the teaching of English while motivating students and also providing a relaxed atmosphere. Such activities are studentcentered; hence by using them we give learners a chance to express themselves, enjoy themselves during learning, and use the resources of their own minds.

\section{Criteria for Selecting Instructional Activities}

The choice of games, songs, and stories is cultural, as these activities have all been means of educating and entertaining African children even before the introduction of Western formal education. The use of such culturally familiar materials, though in a new context, helps to situate the Nigerian learner comfortably in the learning environment. However, these activities are 
usually used more in junior than senior classes, and when they are employed, they are used sparingly because teachers feel an obligation to ensure that the syllabus is covered. Thus each of the activities used in this study attempts to reflect suggestions from researchers as to how to design engaging in-class activities that increase the amount of time that students spend on tasks. Therefore, although initially it may seem that time is perhaps being wasted, as students become more motivated, learning actually proceeds faster and more effectively.

The songs and stories selected for this study emphasize the relationship between course materials and students' own lives, thus highlighting how learning can be useful in real-life situations (Lumsden, 1994). This makes schoolwork meaningful to students both inside and outside the school (Policy Studies Associates, 1995). Furthermore, in line not only with Policy Studies Associates, but also with Anderman and Midgeley (1998) and Brooks, Freiburger, and Grotheer (1998), students in this study were allowed to have some degree of control over the learning process. For example, students were given an opportunity to (a) make choices between various familiar songs relevant to the topic to be learned; (b) minimize adult supervision over group projects by working on the word games in groups, and (c) monitor and evaluate their own progress as they followed the stories. In line with Dev (1997), they found that the tasks were challenging (not merely rote and repetitive) but still achievable (not discouraging); consequently, there was evidence that they put in a lot more effort than they would otherwise have done. All the selected activities helped to arouse students' curiosity about the topic to be studied, as suggested by the mystery approach in Strong, Silver and Robinson (1995). Involving the whole class in the tasks helped learners to share new knowledge among themselves and not just with the teacher, as also discussed by Strong et al.

\section{Research Methodology}

The design of the study was experimental. The study adopted a pre-testpost-test control group design. The population comprised all the 10 public secondary schools in the Ife East Local Government Area of Osun State in Nigeria. One school was purposely selected from this population. One hundred Senior Secondary School (SSS) II students from this school participated. The rationale for focusing on SSS II students was their poor performance in English language at a stage when they were already being prepared for major external examinations. Also, there was the need to examine objectively the belief of some teachers that cultural activities were no longer necessary at the SSS level.

\section{Research Instruments}

The research instruments used were: 
1. Questionnaire on Students' Motivation in the Learning of English

(QSMLE),

2. Achievement Test in English Language (ATEL),

3. Instructional Package, and

4. Oral Interview.

\section{Questionnaire on Students' Motivation}

in the Learning of English (QSMLE)

This instrument was a questionnaire with two sections. Section A sought to elicit personal information such as sex and age from each student. Section B, with 20 Likert-scale questions, sought to gather information on students' present motivational state and on their interest in the English language and in the use of word games, songs, and stories in the English language classroom. In this section each statement had five options with the following weights: Always 4; Sometimes 3; Undecided 0; Rarely 2; and Never 1 (Appendix B).

\section{Achievement Test in English Language (ATEL)}

The test was used to measure the students' entry and post-treatment performance on some specific topics taught with respect to the following aspects of English: (a) comprehension, (b) idiomatic expressions, and (c) vocabulary development.

The test contained essay items, which focused on comprehension, as well as objective questions, which centered on idiomatic expressions and vocabulary development (Appendix C).

\section{Instructional Package}

The non-standardized instructional package covered topics of interest taught under the aspects of English already identified. Although learners were exposed to word games grouped into four sets and four culture-based stories prepared by the teacher, they were also encouraged to suggest four songs in their mother tongue appropriate for the topic of each day. The word games were used to teach idiomatic expressions; the stories were used for comprehension; and the songs were used to develop students' vocabulary. The topics taught under the various language aspects were derived from the syllabus through the use of a table of specifications. The period for teaching and for the post-test was three weeks, spanning 15 classroom periods. The experimental group was taught using the package designed to inspire and motivate them to learn. The control group was exposed to conventional teaching (Appendix D).

Oral Interview

Thirty students from the experimental group were randomly selected and interviewed after the period of teaching to find out how they rated the 
culturally relevant instructional activities that had been used. Students' responses are shown in Appendix E.

\section{Validation of Research Instruments}

The instruments were validated: the Questionnaire and Test were administered twice to 30 SSS II students in a public school comparable to the school that was selected for the research. The Questionnaire was the first to be administered. This same exercise was repeated with the same set of participants after two weeks. A test-retest reliability index $(r)$ of $0.78(n=30)$ was obtained. The Test was then conducted covering specific topics in English with the same set of 30 SSS II students. Once again, this exercise was repeated with the same set of participants after two weeks. A reliability index $(r)$ of $0.87(n=30)$ and a difficulty range $(P)$ of between 0.10 and 0.43 were obtained. These results suggest that the instruments are valid and reliable and that the Test has a moderate difficulty level.

\section{Procedure}

The experiment lasted three weeks. A pre-test was initially administered to both control and experimental groups. Then students in both groups were taught four comprehension passages in the first week. Whereas the experimental group was taught via culturally relevant stories, the control group was taught without such activities. Each comprehension passage was taught for a period of 40 minutes. Thereafter, both groups were exposed to the same post-test.

In the second week, students were exposed to topics such as education, health, transport, and farming under vocabulary development. Whereas those in the experimental group were encouraged to suggest and sing songs relevant to the topics taught, those in the control group were not. An attempt was made in both groups to teach vocabulary items by relating the topics to students' day-to-day activities. Thereafter a post-test was conducted.

In the third week, students were taught idiomatic expressions. Those in the experimental group were divided into two teams. Idiomatic expressions were introduced: a point was awarded to the team (not the individual) providing a correct meaning for each expression highlighted. Those in the control group attempted to find answers to expressions individually. A post-test was then conducted after the exercise in both groups.

\section{Data Analysis}

Responses obtained from the Test and Questionnaire items were scored. The essay responses were scored using an analytical/point scoring method, and the conventional one-correct-answer method was used for the multiplechoice items for both groups. For the Questionnaire, the total score for each respondent was obtained by adding the weights assigned for the options 
chosen by the respondent. Thereafter, the relationship between students' level of motivation and their performance in English language was obtained through Pearson's Product Moment Correlation; $t$-test analysis was used to evaluate the difference between the motivational and performance levels of students in English.

\section{Results and Discussion}

Hypothesis 1. There is no significant relationship between senior secondary school students' present motivational level and their performance in English language.

To test this hypothesis, the motivational levels of both the experimental and control groups were related to their performance in English using Pearson's Product Moment correlation, as presented in Table 1. Table 1 shows that there was no significant relationship between students' level of motivation and performance in English language before treatment. The null hypothesis is therefore retained.

Hypothesis 2. There is no significant difference in the motivational level in English language of those taught through word games, songs and stories, and those taught without them.

To test this hypothesis, the pre-test and post-test motivational level scores of participants in both the experimental and control groups were subjected to a number of t-test statistical procedures. The results are presented in Table 2. Table 2 shows mean motivational level pre-test scores of 36.96 and 38.18 for the experimental and control groups respectively, and standard deviation scores $(S D)$ of 8.32 and 8.86 for the experimental and control groups respectively before treatment. A $t$-test analysis on these values yielded a $t$-value of $-.709(d f=49, p>0.05)$. This suggests that the two groups were not significantly different in their motivational levels before the treatment began. However, after treatment, mean motivational level scores of 64.92 and 48.00 were obtained for the experimental and control groups respectively, with $S D$ of 2.35 and 8.40 for the experimental and control groups respectively. The post-test score of the experimental group $(x=64.92, S D=2.35)$ was compared

Table 1

Relationship Between Students' Present Motivational Level and Their Performance in English

\begin{tabular}{lccccc}
\hline Group & $N$ & $\bar{x}$ & $S D$ & $r$ & $P$ \\
\hline $\begin{array}{l}\text { Level of Motivation } \\
\text { Performance in English } \\
\text { Language }\end{array}$ & 100 & 37.57 & 8.57 & & \\
& 100 & 1.74 & 1.18 & & \\
\hline
\end{tabular}


Table 2

Difference in the Motivational Levels of Participants in the Experimental and Control Groups

\begin{tabular}{lcccccc}
\hline Group & $N$ & $\bar{x}$ & $S D$ & $d f$ & $t$ & $P$ \\
\hline Pre-test experimental & 50 & 36.96 & 8.32 & & & \\
Pre-test control & 50 & 38.18 & 8.86 & 49 & -.709 & $>0.05$ \\
Post-test experimental & 50 & 64.92 & 2.35 & & & \\
Post-test control & 50 & 48.00 & 8.40 & 49 & $* 13.70$ & $<0.05$ \\
Pre-test experimental & 50 & 36.96 & 8.32 & & & \\
Post-test experimental & 50 & 64.92 & 2.35 & 49 & $*-22.85$ & $<0.05$ \\
Pre-test control & 50 & 38.18 & 8.86 & & & \\
Post-test control & 50 & 48.00 & 8.40 & 49 & -5.86 & $>0.05$ \\
& & & & & & \\
\hline
\end{tabular}

${ }^{*}$ Significant

with the post-test score of the control group $(x=48.00, S D=8.40)$; the $t$-test analysis yielded a significant $t$-value index of 13.70, which supports the interpretation that the improvement in the motivational level of the experimental group after treatment may be attributed to the effect of the treatment.

Comparison of the pre-test and post-test scores of the control group $(x=38.16, S D=8.86$; and $x=48.00, S D+8.40)$ was also carried out. This analysis yielded a $t$-value of $-5.86(d f=49, p>0.05)$. This suggests that participants in the control group did not exhibit any significant improvement in their level of motivation, whereas the experimental group did, which again is consistent with the interpretation that the improvement in the motivational level of the experimental participants could be attributed to the effect of the treatment. The null hypothesis is therefore rejected.

Hypothesis 3. There is no significant difference in the post-treatment performance in English of those taught through word games, songs, and stories and those taught without them.

To test this hypothesis, the pre-test and post-test performance in English of participants in both the experimental and control groups were subjected to $t$-test statistical procedures. The results are presented in Table 3. Table 3 shows mean pre-test performance scores of 1.68 and 1.80 for the experimental and control groups respectively, and SD of 1.28 and 1.08 for the experimental and control groups before treatment. A $t$-test comparison of these values yielded a $t$-value of $-.504(d f=49, p>0.05)$. This suggests that the two groups were not significantly different in their performance before the treatment began. By contrast, after treatment, the mean performance scores for the experimental and control groups were 8.24 and 2.44 respectively, with 
Table 3

Difference Between the Performance in English of Participants in Experimental and Control Groups

\begin{tabular}{lcccccc}
\hline Group & $N$ & $\bar{x}$ & $S D$ & $d f$ & $t$ & $P$ \\
\hline Pre-test experimental & 50 & 1.68 & 1.28 & & & \\
Pre-test control & 50 & 1.80 & 1.08 & 49 & -.504 & $>0.05$ \\
Post-test experimental & 50 & 8.24 & 2.39 & & & \\
Post-test control & 50 & 2.44 & 0.92 & 49 & $* 15.96$ & $<0.05$ \\
Pre-test experimental & 50 & 1.68 & 1.28 & & & \\
Post-test experimental & 50 & 8.24 & 2.39 & 49 & $*-17.06$ & $<0.05$ \\
Pre-test control & 50 & 1.80 & 1.08 & & & \\
Post-test control & 50 & 2.44 & 0.92 & 49 & -3.16 & $>0.05$ \\
& & & & & &
\end{tabular}

${ }^{*}$ Significant

SD of 2.39 and 0.92 for the experimental and the control groups respectively. The post-test scores of the experimental and the control groups were compared: $t$-test analysis yielded a significant $t$-value index of 15.96, suggesting that the experimental group's improvement in performance in English could be attributed to the effect of the treatment adopted.

In addition, comparison of the pre-test scores of the control group $(x=1.80$, $S D=1.08)$ with their post-test scores $(x=2.44, S D=0.92)$ yielded a $t$-value of $-3.16(d f=49, p>0.05)$. This suggests that participants in the control group did not exhibit any significant improvement in their performance in English at the end of the treatment, whereas the experimental group did, a result that is also consistent with the interpretation that the improvement in the performance in English of the students in the experimental group could be attributed to the effect of the culturally relevant instructional activities used in motivating students in learning the English language. The null hypothesis is therefore rejected.

Hypothesis 4. There is no significant difference between the post-treatment motivational levels of male and female senior secondary school students in English language. To test this hypothesis, the pre-test and post-test motivational level scores of the two sexes were subjected to $t$-test analysis. The results are presented in Table 4 . Table 4 shows mean motivational scores of 35.92 and 38.00 with SD of 7.15 and 9.38 for male and female groups before treatment. A $t$-test comparison of these scores yielded a $t$-value of -.882 $(d f=49, p>0.05)$. This suggests that the two groups were not statistically different in their motivational levels before treatment. After treatment, there were mean motivational scores of 65.56 and 64.28 , with SD of 2.23 and 2.33 for the male and female groups respectively. A statistical test of the sig- 
Table 4

Difference in the Motivational Levels of Male and Female Students

\begin{tabular}{|c|c|c|c|c|c|c|c|c|}
\hline Score & & $N$ & $\bar{x}$ & $S D$ & $\begin{array}{c}\text { Mean } \\
\text { Difference }\end{array}$ & $d f$ & $t$ & $p$ \\
\hline Before & Male & 25 & 35.92 & 7.15 & & & & \\
\hline Treatment & Female & 25 & 38.00 & 9.38 & -2.08 & 49 & -.882 & $>0.05$ \\
\hline After & Male & 25 & 65.56 & 2.23 & & & & \\
\hline Treatment & Female & 25 & 64.28 & 2.33 & 1.28 & 49 & 1.97 & $>0.05$ \\
\hline
\end{tabular}

nificance of the difference between the post-treatment scores of the two groups revealed a $t$-value of $1.97(d f=49, p>0.05)$. This suggests that the treatment activities designed to motivate students had no significantly differential effect on the motivational levels of male and female students. Consequently, the null hypothesis is retained.

\section{Conclusion}

In the Nigerian school system, English language is one of the compulsory subjects. Using a variety of motivating instructional activities in teaching this subject (even at the senior secondary school level) can play a significant role in improving students' performance; such activities serve as an effective motivational strategy for both male and female students who are learning English, which in turn can contribute to better performance in the subject.

\section{The Authors}

Yetunde Ajibade's areas of interest are in general instructional strategies at all levels of education, language education, and curriculum development. She started her teaching career in Obafemi Awolowo University, Ile-Ife, Osun State, Nigeria in 1983. She pioneered the establishment of a language development center here.

Kate Ndububa, Ambassadors' College, Ile-Ife, Osun State, Nigeria, is an English-language teacher and an examiner of English internal and external examinations for senior secondary school students in Nigeria. She obtained her first degree in education (English) and is awaiting Senate approval for the award of a master's degree in language education.

\section{References}

Adeyanju, O.J. (1996). Effects of repetition of audio-taped instruction and cued visuals on cognitive imagery skills among junior secondary school art students in Ile-Ife. Unpublished doctoral dissertation, Obafemi Awolowo University, Nigeria.

Allen, J.W., \& Vallette, E.D. (1977). Classroom teaching of foreign languages and English as a second language. Chicago, IL: University of Chicago Press.

Ames, C. (1992). Classrooms: Goals, structures and student motivation. Journal of Educational Psychology, 84, 261-271.

Anderman, L.H., \& Midgley, C. (1998). Motivation and middle school students. (ERIC Document Reproduction Service No. ED 421281) 
Bomia, L., Beluzo, L., Demeester, D., Elander, K., Johnson, M., \& Sheldon, B. (1997). The impact of teaching strategies on intrinsic motivation. (ERIC Document Reproduction Service No. ED 418925)

Brocklehurst, B. (1971). Response to music. London: Routledge Kegan Paul.

Brooks, S.R., Freiburger, S.M., \& Grotheer, D.R. (1998). Improving elementary student engagement in the learning process through integrated thematic instruction. Unpublished action research project, Saint Xavier University. ERIC Document Reproduction Service No. ED 421274)

Brophy, J. (1986). On motivating students. (ERIC Document Reproduction Service No. ED 276724)

Bruner, J. (1986). Actual minds, possible worlds. Cambridge, MA: Harvard University Press

Clark, M.C. (2001). Off the beaten path: Some creative approaches to adult learning. New Directions for Adult and Continuing Education, 89, 83-92.

Dev, P.C. (1997). Intrinsic motivation and academic achievement: What does their relationship imply for the classroom teacher? Remedial and Special Education, 18(1), 12-19.

Hill, D.A. (1999). Traditional folksongs in class. Modern English Teacher, 8(12), 28-33.

Jackson, P.W. (1995). On the place of narrative in teaching. In H. McEwan \& K. Egan (Eds.), Narrative in teaching, learning and research (pp. 3-23). New York: Teachers College Press

Lo, R., \& Fai Li, H.C. (1998). Songs enhance learner involvement. English Teaching Forum, 36(3), $8-11$.

Lumsden, L.S. (1994). Student motivation to learn. ERIC Digest, 92, ED 370200.

Mackay, W.F. (1965). Language teaching analysis. London: Harper and Row.

Maslow, A.H. (1954). Motivation and personality. New York: Harper and Row.

Neuhauser, P.C. (1993). Corporate legends and lore: The power of storytelling as a management tool. New York: McGraw-Hill.

Policy Studies Associates. (1995). Raising the educational achievement of secondary school students: An idea book. Volume I, summary of promising practices. Washington DC: US Department of Education. Retrieved January, 2008, from: http:/ / www.ed.gov/pubs/Raising/vol1/

Rossiter, M.D. (1992). NEWACE social action theatre: Education for change. Continuing Higher Education Review, 56(3), 168-172.

Strong, R., Silver, H.F., \& Robinson, A. (1995). What do students want (and what really motivates them)? Educational Leadership, 53(1), 8-12. 


\section{Appendix A}

Results of Candidates at the Senior School Certificate Examinations (SSCE) May/June in English (2000-2003)

\begin{tabular}{|c|c|c|c|c|c|c|c|c|c|c|c|c|c|}
\hline \multirow[t]{4}{*}{ Year } & \multirow{4}{*}{$\begin{array}{l}\text { Total } \\
\text { Entry }\end{array}$} & \multirow{4}{*}{$\begin{array}{c}\text { Total } \\
\text { Sat }\end{array}$} & \multicolumn{10}{|c|}{ Number and Percentage Obtaining Grade } & \multirow{4}{*}{$\begin{array}{l}\text { Fail } \\
\text { Fg }\end{array}$} \\
\hline & & & \multirow[b]{3}{*}{ A1 } & \multicolumn{3}{|c|}{ Credit and Above } & \multirow[b]{3}{*}{ C5 } & \multirow[b]{3}{*}{ C6 } & \multirow{2}{*}{$\begin{array}{l}\text { Total } \\
\text { Credit }\end{array}$} & \multirow[b]{3}{*}{ D7 } & \multirow{3}{*}{$\begin{array}{c}\text { Pass } \\
\text { E8 }\end{array}$} & \multirow[b]{3}{*}{$7-8$} & \\
\hline & & & & & & & & & & & & & \\
\hline & & & & B2 & B3 & $\mathrm{C} 4$ & & & $1-6$ & & & & \\
\hline \multirow[t]{2}{*}{2000} & 643,378 & 636,064 & 137 & 525 & 6,453 & 7,135 & 12,222 & 42,320 & 68,792 & 66,941 & 92,088 & 159,029 & 408,243 \\
\hline & & & 0.02 & 0.08 & 1.01 & 1.12 & 1.92 & 6.65 & 10.81 & 10.52 & 14.47 & 25.00 & 64.18 \\
\hline \multirow[t]{2}{*}{2001} & $1,040,101$ & $1,025,027$ & 1,155 & 4,172 & 40,871 & 35,749 & 51,330 & 133,974 & 267,251 & 154,710 & 162,057 & 316,767 & 441,009 \\
\hline & & & 0.11 & 0.40 & 3.98 & 3.48 & 5.00 & 13.07 & 26.07 & 15.091 & 5.81 & 30.90 & 43.02 \\
\hline \multirow[t]{2}{*}{2002} & 925,289 & 909,888 & 618 & 2,440 & 28,636 & 28,167 & 42,906 & 120,801 & 223,568 & 145,421 & 153,141 & 298,562 & 387,758 \\
\hline & & & 0.06 & 0.26 & 3.14 & 3.09 & 4.71 & 13.27 & 24.57 & 15.981 & 6.83 & 32.81 & 42.61 \\
\hline \multirow[t]{2}{*}{2003} & 939,507 & 929,271 & 336 & 1,562 & 29,999 & 34,400 & 54,259 & 149,268 & 269,824 & 165,150 & 155,035 & 320,185 & 31,4225 \\
\hline & & & 0.03 & 0.16 & 3.32 & 3.70 & 5.83 & 16.06 & 29.03 & 17.771 & 6.68 & 34.45 & 33.81 \\
\hline
\end{tabular}

Source. 2004 WAEC State Committee Meeting. October 12 and 14, 2004.

\section{Appendix B}

Questionnaire on Students' Motivation

in the Learning of English

This questionnaire contains statements that need your response as each relates to you. There is no right or wrong statement. The information supplied by you shall be

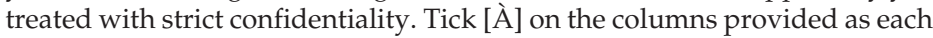
concerns you.

Section A: Background Information

Sex: Male [] Female []

Age: 14 Yrs or less [ ] 25 Yrs [ ] 16 Yrs[ ]

$17 \mathrm{yrs} \quad[$ ] 18 Yrs or more [ ]

Parental Education

Father: Did not attend school

Passed Primary School

Passed Secondary School

Passed ND/NCE

Passed B.A./B.Sc./B.Ed.

Passed M.A./M.Sc./M.Ed. or more

Mother: Did not attend school

Passed Primary School

Passed Secondary School

Passed ND/NCE

Passed B.A./B.Sc./B.Ed.

Passed M.A./M.Sc./M.Ed. or more 
Parental Occupation:

Father:

Mother:.

Section B

1. I like the English Language.

2. I like those who speak English.

3. I like to speak English like those who speak it well.

4. I like reading English books.

5. I like reading English with my father at home.

6. I speak English with my mother at home.

7. I like watching and listening to English programs.

8. I look forward to English lessons.

9. I find the English class interesting.

10. My teacher uses songs to teach us during English class.

11. My teacher tells us interesting stories during English class.

12. We play games in our English lessons.

13. I don't like missing my English Class.

14. I participate in discussions during English lessons.

15. I like my English teacher.

16. My English teacher likes me

17. I pass my English Language tests and examinations.

18. I force myself to listen to the teacher during English lessons.

19. I find English too difficult.

20. I like it when my teacher gives assignments in English.

\section{Appendix C}

Achievement Test in English Language

Comprehension

Instruction: Read the passage below and answer the questions that follow.

The Promotion Exercise

As I sat down there, waiting for the result, my pulse beat faster. It was as if my heart was protesting violently against its imprisonment in the rib cage. For the past

twenty-four hours, I had hardly slept. Yet, long before then I had counseled myself to be calm, courageous and to face whatever was to come as a man. After all, I had done my best and had never been found wanting in my academic work. So far, the few available reports on my work were quite encouraging. Indeed, going by what I 
had heard from the grapevine, I should have a very high rating. So, why this restlessness almost to the point of nervous breakdown?

I had lost my appetite since the previous day; my favorite dishes had become tasteless. My wife had prevailed on me to swallow some morsels of "foofoo," but I had eaten rather mechanically to please her. Then I tried to do some reading. I took up the latest issue of the "International Digest." My eyes saw the lines but my brain did not assimilate anything. The analysis of the country's political crisis failed to excite me. It was mostly a futile exercise. Rather, what registered on my mind was the ongoing meeting of the wise men and women poring laboriously over facts and figures connected with the promotion exercise. I imagined them arguing about who should be promoted, who should not and why? Countless times, I imagined them arguing my case, for and against. Each time, my heart missed a beat. I gave up reading when the magazine fell to the ground.

I got up and started pacing up and down. Then I stepped out and walked slowly towards the road. I crossed to the other side and strolled to the pond almost hidden by a shrub. I stopped at its edge and gazed into the water, seeing the reflections of the trees and leaves, the sky and of course, my face. I think I was attracted by my own image, I wouldn't know, but I really fixed my eyes on it for long minutes. Somehow, I was thrilled by the way my face floated on the lake against the background of the bluish sky.

Then from afar, I heard someone shout my name. I looked up and there across the road was my friend, Marcus, shouting excitedly "Congratulations!

Congratulations!!" I was so caught unawares that I did not know whether to cry or laugh.

Questions

1. What was the writer waiting for?

2. Mention two indications of his anxiety.

3. Mention one subject matter contained in the magazine the writer tried to read.

4. What occupied the writer's mind as he tried to read?

5 . What result did the writer get in the end?

6. How do you know?

7. What figure of speech is the expression "my heart was protesting violently against its imprisonment"?

8. Why do you consider it so?

Idiomatic Expressions

Choose the option that is the most appropriate interpretation for each of the following statements.

1. The woman went out of her mind when she learnt of her child's kidnap. This means the woman became

(a) angry

(b) crazy

(c) restless

(d) unconscious

(e) uncontrollable

2. Bukola has an infectious smile. This means that Bukola 

(a) spreads infection when she smiles
(b) has sores on her teeth
(c) makes others smile when she smiles
(d) becomes infected when she smiles

3. It is cold comfort to tell a hungry man that starvation improves health. This means that telling a hungry man this is
(a) frightening
(b) consoling
(c) unhelpful
(d) hypocritical

4. Nonso's father gave him a free hand to run the family business. This means that his father
(a) assisted him freely
(b) allowed him to make his own decisions
(c) made him sole owner of the business
(d) allowed him freedom of movement in the premises.

5. You must be speaking with your tongue in your cheek. This means that you

(a) must be very serious

(b) must be thinking of something else

(c) have food in your mouth

(d) don't mean what you are saying.

Vocabulary Development

Instruction: Decide which word A, B, C, D or E best fits each space

Waking up by 9.00 a.m., I knew I was late to listen to the news 1 or the usual newspaper 2. A short while later, I heard the voice of 3 making his daily 4 I quickly dashed outside and called him. He was carrying a heap of papers on his left arm but I 5 only two 6 of different dailies.

$\begin{array}{lllll}\text { A } & \text { B } & \text { C } & \text { D } & \text { E } \\ \text { Analysis } & \text { Broadcast } & \text { Commentary } & \text { Coverage } & \text { Presentation } \\ \text { Discussion } & \text { Preview } & \text { Reading } & \text { Review } & \text { Sampling } \\ \text { Journalist } & \text { Newsagent } & \text { Newspaperman } & \text { Reporter } & \text { Vendor } \\ \text { Call } & \text { Round } & \text { Run } & \text { Shift } & \text { Trip } \\ \text { Borrowed } & \text { Collected } & \text { Received } & \text { Recovered } & \text { Retrieved } \\ \text { Copies } & \text { Editions } & \text { Titles } & \text { Units } & \text { Versions }\end{array}$

Make a sentence with the word "publication."

\section{Appendix D}

Instructional Package

Stories

1. A woman called Abike lived in a town called Ejigbo. She had been married for fifteen years without any child. She was highly victimized and neglected by her in-laws and even some people around, all because of her situation. Eventually, she got pregnant and delivered a set of twins. She was now loved and accepted in the environment. But then she was advised to take the twins to the Motor-Park, Market Square and all over the place to beg for alms. She never liked the idea but then she never had a choice but to do that because it was the tradition in the land that twin mothers were meant to go out and beg for alms. 
2. A boy called Dayo who was an orphan lived with his old uncle in a remote village in Ondo State. He liked the idea of living in the village but then he wanted to live a better life as he felt there were more prospects in the city. So, he requested to live with his uncle in Lagos. On his uncle's invitation, he was highly excited and imagined so many nice things about Lagos. On getting there, the reverse was the case as he never enjoyed the peace and quietness he enjoyed in the village. Around his neighborhood were blaring sounds coming from speakers. His neighbors were not helping matters as their radio sets were always on. He longed for his peaceful home no matter how poor it was.

3. There was a boy called Ayo, an undergraduate at the University of Ibadan. During his third year in the University, he won a Visa Lottery to the United States of America. He had no choice but to abandon his program and opt for traveling abroad. Having spent fifteen (15) years in the United States, he came back to Nigeria having adopted their lifestyle over there. He found it quite difficult acclimatizing back home. But his friends were envious of him; they wanted to dress like him, speak like him and walk like him.

4. There was once a man called Mr. Ajayi, a successful cocoa farmer. He was quite hardworking and rich. He felt he would not be fulfilled until he had a polygamous home. And so, he went ahead and married three wives and had eighteen children. This he considered a great achievement since his father had two wives and thirteen children. He felt each of his children would be in a position to assist him in his business. But then, there was envy, hatred and disunity among his wives and children. And rather than being fulfilled like he earlier thought he became a confused man.

\section{Songs}

1. Ji kororin, We koomo, Geekanan re, Foso re,

Jeun to dara

lasiko, maa se sobun.

Imototo lole segun arun gbogbo,

Imototo lole segun arun gbogbo,

Imototo ile, imototo ara, imototo omi, Imototo lole segun arun gbogbo.

2. Oni moto, oni moto, ma se sare asapajude $\mathrm{o}$,

Wako pelu suuru,

Oni moto, Oni moto, mafe mi ara re sofo ye $o$

Sora ere sisa lewu.

3. Ise oko pe, ise oko pe

Be bi n pa mi ma yaa je bepe

Ise Oko pe.

A $n$ jaye loko bi awon ijoye ni

A n jaye loko bi awon ijoye ni

Ori okere, ori aparo tere lori iyan
Wake up and brush,

Bathe very well, cut your

nails and wash your clothes.

Eat good food at the right time, don't be dirty.

Driver, driver, don't speed

Drive carefully.

Driver, driver, don't

waste your life.

Be careful, it is dangerous to

speed.

Farming is lucrative.

When I'm hungry I eat Pawpaw.

Farming is lucrative.

We do enjoy life and farm like chiefs. We do enjoy life and farm like chiefs.

The squirrel and partridge's 
tirin lofun

A n jaye loko bi awon ijoye ni

4. Eko dara pupo, eko lo laye tawayi se Eko dara pupo, eko lo laye

tawayi se

Eko lo gbe ni debi giga

Eko lo gbe ni debi ola

E dakun ye eyin obi wa

Te ba lowo ke fi to wa. heads adorn

The pounded yam on our plates.

We do enjoy life on the farm like chiefs.

Education is good, it dominates the present world.

Education is good, it dominates the present world.

Education takes us to high heights,

Education leads to wealth.

Please, our parents,

If you are well to do, train us.

Games

4. The class is divided into two groups: A and B. Idiomatic expressions are written on the board. Whichever group gets the correct answer scores a point.

Idioms

a) Sail under false colours

b) Smell a rat

c) Follow one's nose

d) Pay through the nose

e) Lead somebody a dog's life

f) Die a dog's death

g) Be left in the cold

h) Chip off the old block

i) Raise the wind

j) Fight one's hand

a) Burn one's boat

b) Be in the same boat

c) Give somebody a black look

d) Sleep the clock round

e) Have a bone to pick with someone

f) Bone of contention

g) Carry the day

h) Build a castle in the air

i) To shed crocodile tears

a) To ride a high horse

b) To kick up one's heels

c) To cool one's heels

d) To lose one's head

e) To hit the (right) nail on the head

f) To have a feather in one's cap

g) To kill two birds with one stone

h) Out of the frying pan into fire

i) Ask for a lady's hand

j) To feed out of one's hand

a) Show white feather

b) See things through rose coloured spectacles Take a cheer

c) Escape by the skin of one's teeth

d) Show one's teeth
Interpretations

Be a hypocrite or impostor

Suspect that something wrong is being done

Go straight forward

Pay an excessive price

Worry somebody all the time

Die in shame or misery

Be ignored

Son who is very like his father

Obtain the money needed

Make known one's intentions or plans

Change one's plans

Have the same dangers to face

Look at somebody angrily

Sleep twelve hours continuously

Have something to argue or complain about

Subject of dispute

Be victorious

Think or plan something that cannot be realized

To shed false tears

To be snobbish or arrogant

To behave excitedly

To be kept waiting

To become confused or excited

To say or do the right thing

To have something to be proud of

To gain two ends at once

Out from a situation to one that is worse

To ask for her as a wife

Be very willing and ready to obey

Show fear

Have a narrow escape from danger

Look very angry 
e) Like a fish out of water

f) Root and branch

g) Help a lame dog over a stile

h) Bite somebody's nose off

i) Come to a head

j) Bite one's lip
Feeling uncomfortable

Thoroughly, completely

Help a person in trouble

Answer him sharply and angrily

Reach a crisis

Try to conceal one's anger

\section{Appendix E}

\section{Students' Ratings of Instructional Activities}

The 30 students randomly selected for interview were asked which of the activities they thought influenced their understanding most in the English Class. Eight mentioned songs, 12 mentioned stories, and 10 said games, as depicted in Figure 1. When they were further asked about the activity they liked most, nine indicated their preference for songs, 13 identified stories, and eight indicated games. It is interesting to note that the order of preference is the same for both questions, with stories being the most popular as well as the most influential (Figure 2).

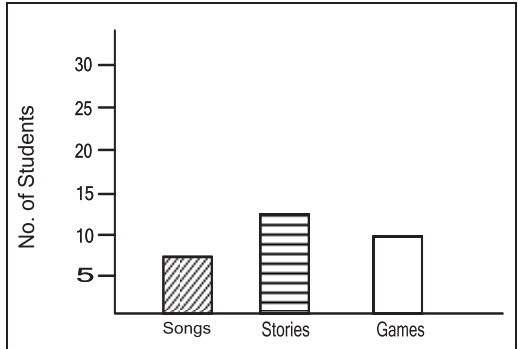

Figure 1. Influence of activity on students' understanding.

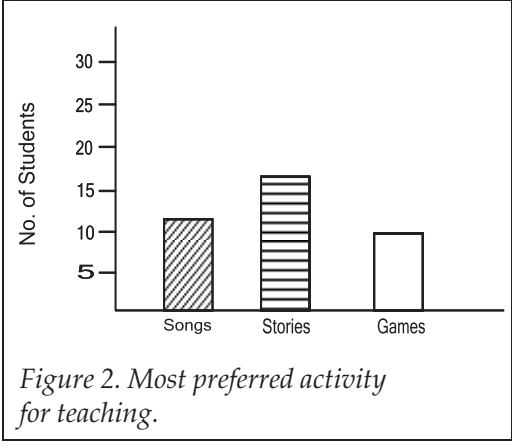

preferred activity for teaching. 